Article

\title{
Planning from Failure: Transforming a Waterfront through Experimentation in a Placemaking Living Lab
}

\author{
Ramon Marrades ${ }^{1}$, Philippa Collin ${ }^{2, *}$, Michelle Catanzaro ${ }^{3}$ and Eveline Mussi ${ }^{4}$ \\ 1 Placemaking Europe, 3014PM Rotterdam, The Netherlands; E-Mail: ramon.marrades@placemaking-europe.eu \\ 2 Institute for Culture \& Society, Western Sydney University, Parramatta, NSW 2150, Australia; \\ E-Mail: p.collin@westernsydney.edu.au \\ ${ }^{3}$ School of Humanities and Communication Arts, Western Sydney University, Parramatta, NSW 2150, Australia; \\ E-Mail:m.catanzaro@westernsydney.edu.au \\ ${ }^{4}$ Faculty of Built Environment, University of New South Wales, Kensington, NSW 2052, Australia; \\ E-Mail: e.mussi@unsw.edu.au \\ * Corresponding author
}

Submitted: 15 August 2020 | Accepted: 22 December 2020 | Published: 26 March 2021

\begin{abstract}
This article assesses what happens when planning by experiment becomes imperative for strategic city sites such as waterfronts due to the failure of other forms of centralised, top-down, or market-led planning. Through an in-depth case-based analysis of La Marina de València (LMdV) we investigate the potential of experimentation for revitalisation of city sites. To do this, we first review the literature on urban development approaches to identify specific issues that lead to urban planning failure. We then extend the scholarship on urban experimentation by proposing a definition of place-based experimentation as 'relational process.' Then, we explore how planning by experiment emerged as a response to planning failures in a broader strategy for revitalisation of LMdV. We propose key processes for planning by experiment through a Placemaking Living Lab based on perception, collaboration, and iteration, which we use to assess experimentation at LMdV. In the conclusion we discuss the potential of this approach to 'planning by experiment' to revitalise urban governance and planning processes in cities and their strategic sites.
\end{abstract}

\section{Keywords}

experimental planning; innovation; participation; placemaking; urban living labs

\section{Issue}

This article is part of the issue "Urban Planning by Experiment" edited by Christian Scholl (Maastricht University, The Netherlands) and Joop de Kraker (Maastricht University, The Netherlands).

(C) 2021 by the authors; licensee Cogitatio (Lisbon, Portugal). This article is licensed under a Creative Commons Attribution 4.0 International License (CC BY).

\section{Introduction}

Worldwide, waterfront regeneration megaprojects have become key post-industrial sites of entrepreneurial planning strategies to revamp a city's international image (Marshall, 2001) - attracting investment and footloose capital, and iconic architectural symbols of economic power (Kennedy, 2015; Orueta \& Fainstein, 2008). Proposals for their regeneration are usually justified by promises of social, economic, and environmental benefits (Laidley, 2007). However, such aims are often reduced to rhetoric and broken promises (Flyvbjerg, 2005), while megaprojects unfold as antagonistic processes between developers, authorities, and local communities (Sandercock \& Dovey, 2002; Siemiatycki, 2013).

Despite the multifaceted issues around waterfront regeneration, there is often ongoing commitment from state and specialised planning authorities to realise social, economic, and environmental benefits. In this article we consider one such strategic waterfront site: 
La Marina de València (hereafter LMdV), Spain -the old harbour of one of the largest ports in Mediterranean Europe. Through different phases of urbanisation (Hall \& Barrett, 2012), waterfronts sites have been key strategic areas of mercantile exchange, industrialisation and, later, of cultural modes of capital exchange. While planning strategies and urbanisation processes have changed over time reflecting economic and political changes, dominant underlying values and outcomes remain influential and contested. Though some sites have seen environmental and aesthetic improvements led by more recent design strategies, the continued focus of planning efforts on profit-value over user-value have compounded long histories of dislocation, under and over development, and economic, political, and climate crises.

Within the discourse of multiple crises, urban experimentation is gaining increasing importance. With associated approaches such as living labs and placemaking, experimentation is increasingly seen as necessary for addressing new or intractable urban challenges (Bulkeley et al., 2016; Caprotti \& Cowley, 2017) and a potentially valuable mode of planning (Scholl \& Kemp, 2016). This potential raises questions about the 'urban planning challenges' to be addressed as well as the approaches, participants, and outputs of urban experimentation processes. How can experimental processes generate new knowledge, relationships, and mechanisms that embed a commitment to experimentation and improving governance? This article aims to make a conceptual and empirical contribution to the literature by responding to these questions through an investigation of what happens when planning by experiment becomes an imperative due to the failure of other forms of centralised, top-down, or market-led planning for strategic city sites.

The article is based on a three-year collaboration between el Consorcio València 2007 (the administrative agency responsible for $\mathrm{LMdV}$ ) and the Western Sydney University to inform and assess the establishment of a Living Lab at the Marina. Between 2017 and 2020 the authors engaged in regular knowledge exchange and collaborated on some of the experiments conducted at LMdV. A transdisciplinary project, the findings in this article are based on: regular correspondence with members of the Consorcio as the Living Lab was established; observation; participant observation; document, media, and website content analysis; qualitative data generated in workshops and interviews; and secondary analysis from experiments and research conducted by the Consorcio. Our analysis finds that experimentation surfaced and helped focus planning processes on the dynamic relationship between the tangible (physical) and intangible (social and cultural) features of the site-essential for achieving thriving public spaces.

To understand why previous planning approaches have not grasped the importance of this relationship, we begin by critiquing the way different approaches to planning have failed strategic city sites. Then, we consider how experimentation has emerged as a response to the limitations of state and market-led planning paradigms. Identifying the ways experimentation addresses the limitations of other planning approaches, we propose a definition of planning by experiment as relational process. We then introduce the case study-noting that the potential of urban experiments is inextricably tied to the histories of the places in which they are enacted-and apply the relational concept of planning by experiment to assess the integration of planning by experiment in a broader strategy for revitalisation of LMdV. We conclude there is considerable potential in 'planning by experiment' through a Placemaking Living Lab (hereafter PmLL) to revise urban governance and planning-and to productively impact broader planning processes and practices that shape cities and their strategic sites.

\section{Planning and Failure}

Strategic city sites, such as LMdV, have developed over centuries and, since the 1950s, have been subject to different planning approaches. These can be understood as evolving and overlapping with legacies that play out in the present (Table 1). While the pre-industrial phases of urban transformation were characterised by laissez-faire, elite-led urban development with limited state control, the industrial period marked a shift towards a more regulated plan-led system, whereby development processes became increasingly directed by legally-binding zoning plans against which proposals and approvals were determined (Hall \& Barrett, 2012).

However, zoning plans typically lacked collaborative visioning and community building (Deakin, 2011). From the late 1970s, planning approaches shifted towards policies and regulations to development-based and marketled approaches (Parker, Street, \& Wargent, 2018). These approaches, characterised by public-private consortiums and outsourced development proposals, became globally influential particularly in large-scale regeneration projects. This form of 'market-led' planning became a matter of box-ticking, rather than collaboration or reflection, further limiting professional and community participation (Parker et al., 2020). Despite the justification of such approaches and development proposals on the basis of environmental, social, and economic improvements at the local and regional level (e.g., through new infrastructure and the creation of new economic centres), they largely resulted in privatised high-end property markets and isolated urban areas that reflected the desires and visions of a limited number of producers and users of urban space.

At the turn of the millennium, the growing force of the cultural economy and the creative industries generated design-based schemes and initiatives as a driver of economic and social regeneration globally (Freestone \& Gibson, 2006). Still framed by principles of production and consumption, design-led planning was characterised by flagship public, commercial, and residential developments-and which had greater global marketing 
Table 1. Phases of urban planning leading to place-based approaches.

Plan-led planning

From 1950s

Development-led planning

From 1960s

Market-led planning

From 1990s

Design-led planning

From 2000s

Place-led planning

From 2010s
Development proposals are determined by the public authority through a formal zoning plan.

Development proposals are determined by the public authority on case-by-case merits without limitations from a formal zoning plan.

Increased role of the private sector in determining the formulation of master plans, determination of land-use rights, and financial resources. Viability-planning is a derivative.

Based on place branding, marketing, and promotion in combination with infrastructural improvement to stimulate local economic development through the attraction of post-industrial professional, managerial, and service businesses.

Also associated with 'placemaking,' derived from 'place' theory: as multilayered space occupied with human activity, local meaning, and distinctive qualities or 'spirit.' Fundamentally based on community participation and understood as a collaborative process among multiple stakeholders (professionals, officials, residents, and businesses). Spans the planning, design, management, and programming of public space with the purpose of improving a community's cultural, economic, social, and ecological situation. impact when associated with mega sporting events (Bell \& Jayne, 2003). In all, design-led planning approaches boosted the high-end cultural economy of cities, attracting footloose capital and mega-events, but further failed to implement a regeneration process that connected at the local level to provide public spaces that were meaningful to local people (Mussi, Steinmetz, Evans, \& Corkery, 2020). Design-led approaches in many instances reproduced and even deepened the disconnect between development outcomes and local people, cultures, and uses (Sandercock \& Dovey, 2002) and have been heavily critiqued as restrictive and preventative rather than generative of new ideas and practices that result in use of urban space that benefits the broader public (Lovering, 2009; Pickvance, 1982; Yiftachel \& Huxley, 2000).

This brief discussion highlights the persistent conflict between exchange-value (profit) and user-value (everyday life) in configuring the urban. In planning approaches for strategic city sites, exchange-value has dominated, "failing dismally, producing devalorized, crisis-driven urban and regional landscapes in which labour and capital cannot be combined productively to satisfy social needs" (Brenner, Marcuse, \& Mayer, 2012, pp. 3-4). Success has mainly been measured in capital turnover, often resulting in the pursuit of ongoing developments within the same planning approach. Opportunities for learning, revisions in governance, regulations, and smallscale changes for gradual improvement are frequently overlooked. Thus, as cities have evolved, they have become increasingly complex, caught up in an evolving "dichotomy between the planned and the unplanned, the rational and the irrational" (Cupers, 2004, p. 5)requiring new ways of planning for urban transformation.

Place-led approaches offer to bridge the exchange and user value gap by reconceptualising city sites as 'places,' prioritising and responding to changing demands from communities, and focusing on people and not on profit (see Brenner et al., 2012). Importantly, place-based experimental projects that do not result in desired outcomes can still be associated positively with learning (Sendra \& Sennett, 2020), involvement of previously excluded groups, and a shift in the attitude and practices of administering organisations, municipalities, or corporate stakeholders towards collaboration and co-creation (Scholl \& Kemp, 2016, p. 99). In this way, place-based and experimental approaches can be understood as crucial responses to the failure of other planning approaches and as deeply implicated in attempts to reconceptualise how city sites are constituted, to understand how transformation is enacted, and how success and failure are defined.

\section{Experimentation as a Response to Failure}

When understood through the lens of 'places,' citiesencompassing waterfronts-are made up of dynamic human and non-human arrangements that inform city life, that move beyond binary oppositions such as "subject-object, mental-material, natural-social...local [and] global" (see Massey, 1994; Soja, 1996, p. 60). As Cupers (2004, p. 5) argues, through the concept of assemblages, alternative visions of the city are "no longer a dichotomy, but a multitude of (dis)ordering interventions that constitute and transform the urban landscape." Moreover, efforts to grapple with the 'emotional' and 'non-tangible' move beyond the notion of the city as a 'thing' (Farias \& Bender, 2010) and towards understanding the city as a 'place' and an integral actor in the planning network. This relational account of place requires relinquishing 'certainty' and engaging 
with 'the known unknowns' in urban planning processes. Experimental approaches can be understood as a response to the recognition that cities are complex assemblages to which top-down, linear modes of planning are problematic at best. Here we consider the experimental features of two place-based approaches to urban planning-placemaking and urban living labs (ULL) - to propose a definition of 'planning by experiment' that addresses the short-comings of the planning approaches discussed above.

Placemaking is conceptualised as a 'continuous process' and a way of "shaping spaces to create meaningful experiences (in, of and for) people" (Hes, Mateo-Babiano, \& Lee, 2019, p. 2). This involves a usercentred process concerned with urban sustainability by transforming context-specific public spaces through exploratory processes (Project for Public Spaces, 2007). When enacted successfully, placemaking is inherently experimental: An iterative process involving numerous small-scale interventions implemented by collaboration with end-users. Placemaking is a nonlinear process involving tiptoes forward, leaps ahead, backtracks, and repeating steps depending on the context and outcomes. Whether these small interventions are temporary or permanent, the goal is long-term impact towards more sustainable public spaces. Similarly, living labs are "user-centred, open innovation ecosystems based on systematic, user co-creation, integrating research and innovation processes in real life communities and settings" (Steen \& van Bueren, 2017). ULL are place-based and focus on generating knowledge and solutions to multifaceted and transdisciplinary problems and opportunities in cities, such as sustainable transitions (Bulkeley et al., 2016; Steen \& van Bueren, 2017). ULL are not just concerned with place but embedded within it-existing in relation to the histories and institutional, spatial, and temporal dimensions of the places they seek to transform. As such, they have potential to contribute to a broader paradigm shift in urban planning (Scholl \& Kemp, 2016, p. 94).

For both approaches, transforming the role of local authorities from sponsors or administrators to partners and collaborators is critical (Cohen, Almirall, \& Chesbrough, 2016). To distinguish themselves from neoliberal agendas, ULL need to meaningfully remake public space into a thriving place, co-designed and reimagined by community and stakeholders using approaches such as placemaking (Lorne, 2019). To overcome the issue of 'profit-value' over 'user-value,' placemaking must also move beyond urban renewal projects in which 'professional place-makers' (often acting as consultants or advisors) are 'flown in' to recreate or 'fix' problematic spaces, without understanding how local lived experiences or 'everyday encounters' impact upon the value and the consequential use of the space (Fincher, Pardy, \& Shaw, 2016). To address these concerns, the literature on urban experimentation indicates three generative features: (1) learning towards a goal;
(2) increase diversity; and (3) iterative process. These features are generative in the sense that they can produce interventions that result in places holding value for diverse stakeholders, in contrast to the goals of traditional planning modes that have proven unsuccessful thus far.

The first feature is that urban experimentation is focused on learning towards a goal, rather than achieving a predetermined outcome (Ansell \& Bartenberger, 2016, p. 70; Scholl \& Kemp, 2016, p. 92). In comparison to that carried out in laboratories, urban experimentation is a messy assemblage of various actors performing in many, often unpredictable, ways requiring a double measure of observation and intervention (Karvonen \& van Heur, 2014, p. 383). Moreover, in urban contexts, experimentation is more "fluid, open-ended, contingent and political" (Raven et al., 2019, p. 260). Thus, urban experimentation prioritises learning through fostering the relations of people and places-putting people at the centre of planning processes. This involves shifting the focus of change from the actions of macro-level actors and policies to diverse stakeholders and their concrete actions in specific places (Karvonen \& van Heur, 2014). This "process of collaboration and interactive learning" is reliant on networking, involving different enterprises, organisations, science and technology, and other entities and individuals (Smith, 2006, pp. 152-153). Experimentation, therefore, is transdisciplinary and values and leverages diverse knowledges through collaborative practices.

Secondly, through ULL, experimentation can increase diversity of participants in urban transformation processes, emphasising reflexivity in relation to other modes of planning so as to prompt broader adaptations within the system (Scholl \& Kemp, 2016, p. 94). To achieve genuine change, experimental urban planning processes must be more than a supplement to a design-based approach, or corporate lip-service to expectations of 'consultation' or 'co-design' (Bulkeley \& Castán Broto, 2013; Evans, Karvonen, \& Raven, 2016, p. 1). Instead, it requires ongoing critical consideration of 'who' is involved, and who is likely to benefit from the recommendations and outcomes, and who determines what success looks like and how it is measured (Evans et. al., 2016, p. 3). These concerns highlight that to be transformative, urban experiments must aim to question and unsettle established power relations associated with institutional, social, and technical forms of knowledge (Bulkeley et al., 2016).

Thirdly, in contrast with other planning systems that are defined by set visions and linear processes and steps, experimentation is iterative, full of discoveries and failures through 'inefficient urban trial and error' (Jacobs, 1969; Levinthal \& March, 1993; Smith, 2006). Experimentation itself unfolds in temporal and spatial relations with flexible and evolving networks comprising economic, social, and political actors and trajectories (Evans et. al, 2016; Farias \& Bender, 2010). 
Consequently, space becomes a living creation, enacted through actions, connections, and associations, iteratively and over time. This idea of space challenges the traditional conventions of planning that define it as a capitalist construct of relations (Smith, 1982) or state strategies (Brenner, 2004). Instead, space evolves as learning and knowledge is shared through various actor networks to create change.

Based on this understanding of planning by experiment as a process of learning towards a goal, which increases participation and diversity, and depends on iteration as an inherent quality, as discussed in the literature, we propose a definition of planning by experiment as a relational process. To examine this relational process in action, we turn to the case study of LMdV.

\section{La Marina de València: Place-Led Experimentation in Response to Planning Failure}

In this section, we introduce the LMdV and contextualise the emergence of a place-led experimentation approach to highlight that urban experiments are inextricably tied to the histories of the places in which they are enacted. As argued above, planning failures can be linked to a misunderstanding of what a place represents to multiple publics: To successfully 'make' place, place needs to be understood as "the locus of complex intersections and outcomes of power geometries that operate across many spatial scales from the body to the global" (Massey, cited in Kitchin, Valentine, \& Hubbard, 2004, p. 7). After first establishing the genealogy of LMdV, the development of a framework for embedding experimentation in the planning approach at LMdV is presented. By synthesising this framework with our proposed definition of planning by experiment as relational process we identify three specific processes that can be used to assess the potential of experimental approaches to urban planning at strategic city sites.

\subsection{A Brief Genealogy of València's Waterfront}

With 1.5 million habitants, València is Spain's third largest city. In València they say: "Los Valèncianos viven de espaldas al mar," which means "Valèncians live with their backs to the sea." Modern planning efforts have aimed to address the tensions between the 'city' and the 'seaside' that have characterised the city's urban evolution. València's harbour was born, six km from the Roman-founded city, with the need for commerce. Over time, the commercial waterfront grew steadily, with significant infrastructure consolidated during the 20th century (Figure 1). The major expansion, based on the exponential growth of maritime trade, took place in the 1980s - a period of development that generated a new phase of social and environmental tensions.

Throughout the late 20th century, there were numerous plans to connect the city centre with the harbour. The General Land-use Plan, from 1988, included opening to the public the old harbour which, by then, had become obsolete for commercial purposes (Boira, 2013). During the late 1990s and early 2000s, València's municipality promoted urban redevelopment based on tourism, real estate growth, and city branding. This resulted in largescale, flagship developments such as Santiago Calatrava's City of Arts and Sciences, Norman Foster's Conference Hall, and waterfront redevelopment. These projects achieved international attention but exacerbated existing inequalities and divisions in the city (Romero, Melo, \& Brandis, 2015). A key strategy to secure tourism, real estate growth, and international profile for the city was
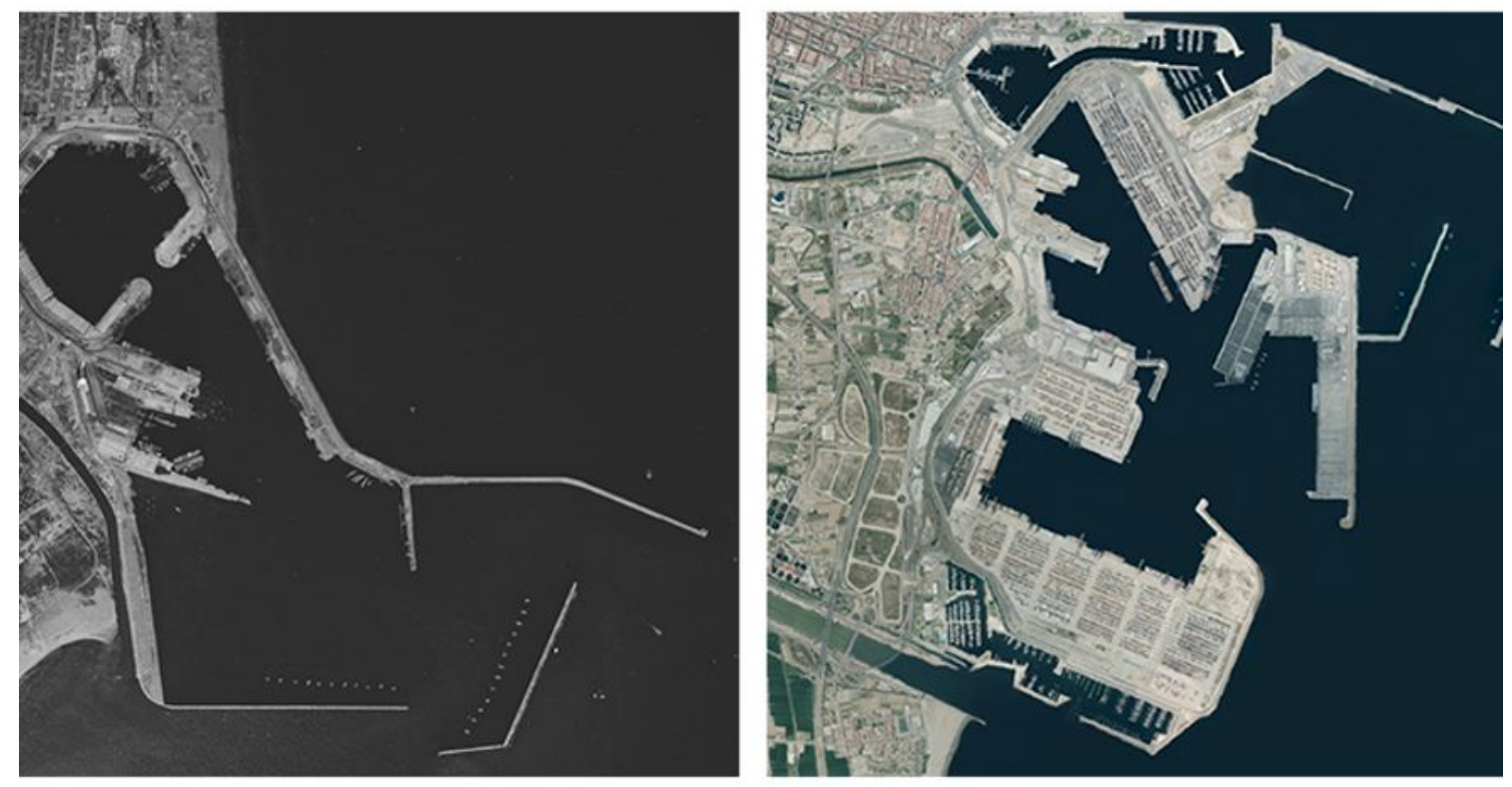

Figure 1. València's harbour in 1947 and 2018. In the right picture we can see LMdV on the upper side. Source: Courtesy of Institut Cartogràfic Valencià. 
to organise a major international event, as Barcelona and Sevilla had both done in 1992 (Olympics and the World Expo respectively). This urban entrepreneurialism and rapid growth policies (Prytherch \& Boira, 2009) reflected a neo-liberal development model (Romero et al., 2015) based also on the long-term alliance between political and market powers linked to the construction of real estate and infrastructure (Sorribes, 2015).

València's 'event' was the 2007 America's Cup of Sailing, followed in 2008 by the European Grand Prix. To host it, a new public institution was created to redevelop the old harbour and waterfront to meet the needs of these events. The Consorcio was established as the waterfront redevelopment agency with the municipal, regional, and Spanish state governments as shareholders. Without a clear plan for post-event uses, major investment was directed towards fitting out the old harbour for the event, including public spaces, construction of twelve team bases, a landmark building for VIP events designed by architect David Chipperfield, a new entrance channel to the old harbour segregated from the commercial port, and three marinas for 800 boats. Following the event, the site became under-used, generating social and economic tensions exacerbated by the severity of the 2008 economic crisis and ongoing proposals for privatisation, leaving the Consorcio with a debt of around 500 million euros.

In 2015 a new government was elected and a new leadership was appointed to lead the Consorcio. This team (which included co-author Ramon Marrades as the chief strategy officer) took a radically different approach to revitalisation of the Marina. To address the major financial debt and continuing lack of use and maintenance of the site, the leadership launched a new strategy in 2017. After the failures brought about by decades of formal regulatory land use plans and development-led and market-led approaches, a place-led approach was adopted and formalised in the LMdV Plan Estratégico 2017-2021 (LMdV, 2017). The plan outlined a new vision based on three fundamental goals:

1. Productive activation of an under-utilised space of high historic, cultural, and real-estate value;

2. Civic engagement and active participation;

3. Effective governance.

At the core of its approach were new strategies to explore alternative outcomes and to create impactful changes. Instead of seeking grand-scheme investments, the strategy prioritised smaller-scale interventions, focusing on uses: putting activation of public space at the core. The Living Lab was specifically created to facilitate knowledge exchange and experimentation using a placemaking approach. Thus, the PmLL served as a conceptual platform for collaboration, especially with desired 'end-users' of LMdV, in identification and codesign of responses to unmet needs. Activation of the network of users, environments, and stakeholders, from conception to implementation of interventions in a real-time context, also allowed for ongoing monitoring and reflexivity.

\subsection{Experimental Urban Planning through a Placemaking Living Lab}

Since 2016, more than 50 experimental processes, at different scales, and involving different groups of stakeholders, have been undertaken to transform LMdV. To support understanding of the experimental approach and to capture the ethos of urban planning and placemaking at LMdV, a manifesto was created with the intention of guiding new ways to reimagine successful city spaces. The Manifesto (LMdV, 2019) synthesised research evidence with professional and situated knowledges in a practical framework. It was created through an open-ended, experimental process drawing on the experiences and knowledge of staff at the Consorcio, businesses operating at LMdV and elaborated during a co-creation workshop with 40 experts, and practitioners and researchers from 15 countries, which took place in November 2018. The Manifesto (LMdV, 2019, p. 38) was:

Born out of the need to define clearly (a) the concept of public space, innovation and the relationship between the two (b) the core values and principles that should guide the creation of public spaces and (c) the key stakeholders that must be involved in the process.

The resultant framework aims to guide all stakeholders when working with the LMdV (Figure 2).

The PmLL manifesto and framework helped articulate the learnings from past experiments to staff at the Consorcio and to local and external stakeholders who were involved, invited, or intending to propose uses at LMdV. The framework intentionally emphasised people, places, and practices for co-creation and action to enhance understanding and legitimacy of the approach. When combined with the three generative features of our definition we posit that planning by experiment through approaches such as placemaking and living labs requires reflexivity through commitments to deeply perceive the place, enhance diversity and embed iteration. Thus, synthesising our proposed definition with the LMdV framework, we propose that an experimental approach to planning from failure is operationalised through the following interrelated processes:

- Perception: Prioritising learning through empirical assessment of needs (data), a systematised response to different stakeholders' requests (demands) and open conversation and co-creation with citizens (hopes or dreams) in an intuitive manner.

- Collaboration: Interrupting hierarchical and market-based power relations and expands the diversity of publics involved in the making of the 


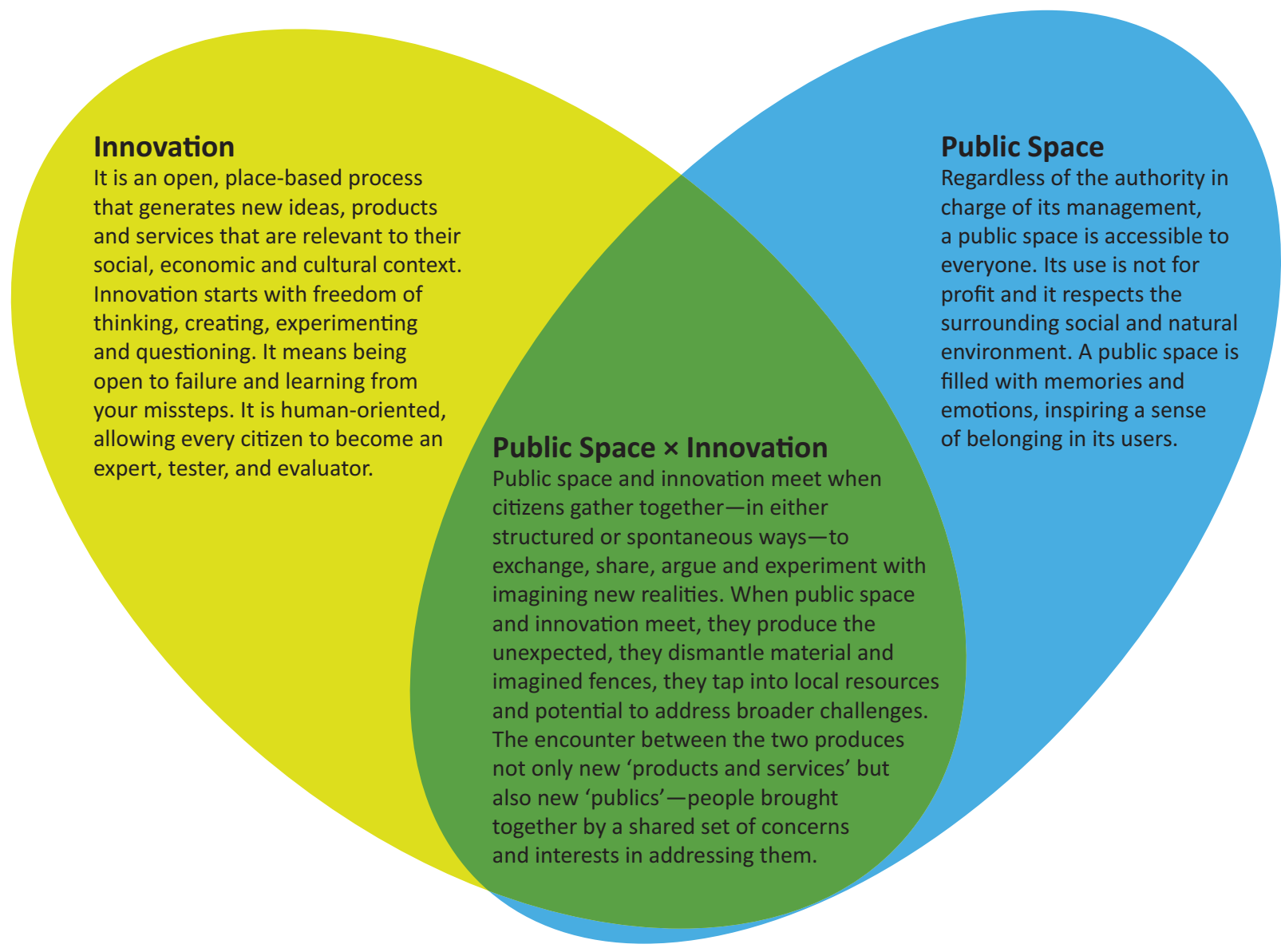

Figure 2. Framework for a PmLL at LMdV (2018). Source: Courtesy of LMdV.

place. Defines who is involved, who is benefiting and who is missing through co-design, co-creation, and co-evaluation.

- Iteration: Embed in institutional governance and strategy to achieve ongoing, approved action. Supports transformation and evolution of the place and leads to the next intuitive experiment and/or to reach out to different actors, involving rethinking, replicating, and rescaling each intervention.

The way these processes are interrelated is captured in Figure 3, and while not entirely linear, the figure illustrates the intent of planning by experiment to result in progressive, positive changes that cumulatively transform urban sites of significant strategic valueand controversy.

These processes were used by the authors to assess how planning by experiment is assisting place-based learning, inclusion, and improvements at LMdV. Our transdisciplinary inquiry draws on key informant summaries, participant observation, secondary data analysis, and document and media analysis. In the next section we provide five short 'intervention vignettes,' purposively selected for their illustrative capacity, to consider how planning by experiment through this framework is assist- ing in the transformation of a failed strategic city site such as LMdV.

\subsection{Learning from Experimentation: Revitalisation of La Marina de València}

Analysis of the PmLL activities identified five aims common to all experiments at LMdV that address failures of past planning approaches and contribute to the Consorcio's strategic goals. These are illustrated below in relation to five vignettes of experiments at $L M d V$ :

1. Turn spaces into places. By 2017, all historical buildings and structures at LMdV had fallen into disrepair. The administrators identified the small bandstand-La Pergola-as a place of particular significance and potential. In collaboration with the Valèncian Music Societies of the surrounding communities, for whom it was a traditional site for concerts and gatherings, a renovation of La Pergola was conducted and a program of weekend concerts featuring the original musicians took place. Attendance numbers and feedback indicated these were popular with local communities and Valèncians. Over four years, the programming for La Pergola has grown and evolved to new 

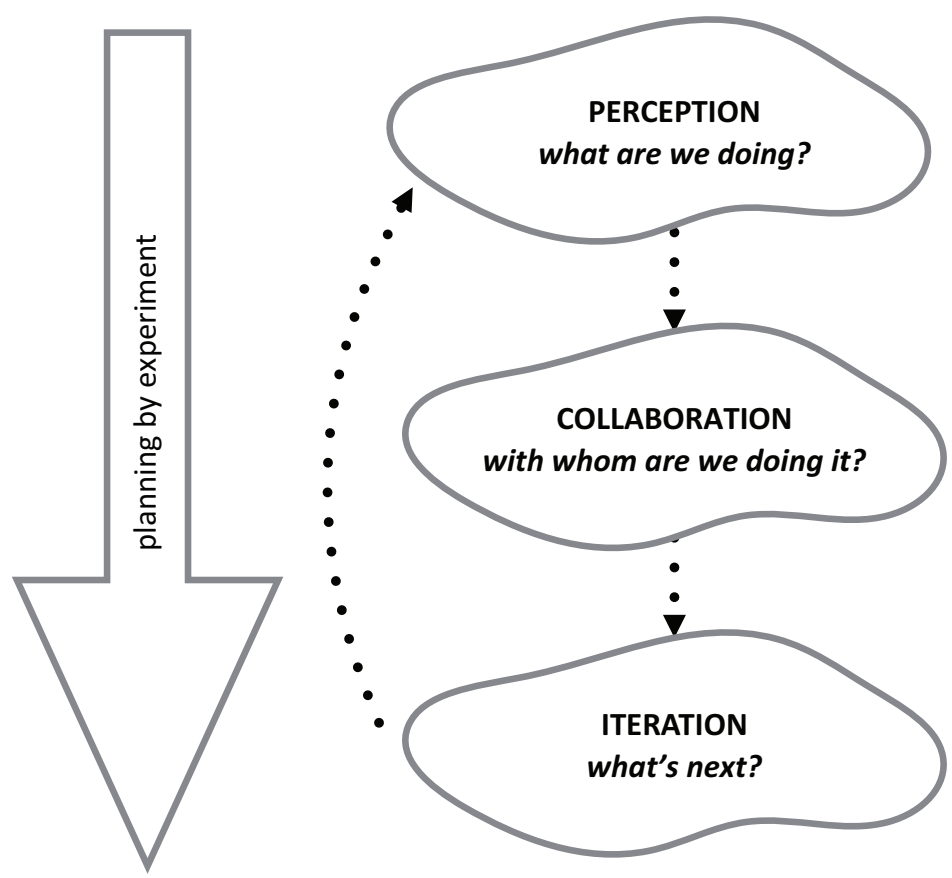

data
demands
dreams

co-design

co-creation

co-evaluation

rethinking

replicating

rescaling

Figure 3. Processes underpinning the approach to planning by experiment at LMdV.

genres and audiences, drawing in a diverse, intergenerational crowd and 'revolutionizing [sic] daytime culture in the city' (El Mundo, 2018).

2. Connect with local identity. Poor local identification with the Marina was identified as a key issue for revitalisation (LMdV, 2017). To improve the everyday engagement of Valèncians with the site, the Veus de La Marina project (2018) engaged local residents, community organisations, and academic, public, and private stakeholders-including waterfront workers and small business ownersto co-create the toponymy of LMdV. Through interviews, surveys, collaborative mapping, and workshops, the project uncovered the history of the space, and developed unique names for the streets and squares in LMdV. The project facilitated a re-appropriation of LMdV's identity by local stakeholders, through a co-creative process of renaming spaces within the precinct. This process was accompanied by the creation of 15 signs for pedestrians and cyclists, five general plans of the site, and 46 general informative signs that address problems of navigation and improving accessibility to the space of LMdV (LMdV, 2020).

3. Broaden user groups. Among other groups, the Marina was not viewed as a place for young people (YP), who were often identified as a 'problem' for the site. To investigate alternative relations, one of the projects was Surem La Marina (2018). The project aimed to dialogue with YP in the surrounding areas, shift negative perceptions, and consider the needs and ideas of YP in a new vision for La Marina, while facilitating participants' learning and empowerment. Over two months, 50 par- ticipants aged 12-14 years visited LMdV weekly for participatory workshops to investigate and 'dream up' ideas to transform the area. Through engaging with YP's experiences of the built and social environment of LMdV and Poblats Maritims (suburbs surrounding LMdV), the project surfaced the preferences, interests, and hopes of participants. YP reimagined the harbour by brainstorming potential interventions to generate value in LMdV, identifying murals, sculptures, and 'artsy things' as well as free and accessible sports facilities as desirable. They also proposed broader goals including making a Marina 'for YP' to address their broader exclusion from other public and private city spaces. Participants' ideas were exhibited at the Consorcio, trialled, or channelled into subsequent co-creation events and other major projects, such as a Skatepark and a basketball court, which also utilised youth-participatory methodologies.

4. Expand public uses. To further develop the idea of a swimming pool proposed by YP in Surem la Marina, and to connect with the historic use of the Valèncian waterfront for public bathing, consultations with local swimming clubs and neighbourhood associations were conducted. These identified the concept of swimming as something that could bring locals and visitors of all ages together at LMdV. Using a 'lighter-quickercheaper' approach, La Marina Ocean Pool was created by employees of LMdV and opened to the public in June 2019, attracting a diverse audience of neighbours, YP, and visitors.

5. Build generative international partnerships. To enhance understanding, capacities, and engage- 
ment in place-based and experimental planning, in 2019 LMdV hosted Placemaking Week Europe. The week-long event was attended by 400 placemakers, politicians, civil servants, developers, and companies who shared best practice, took part in interactive workshops, accelerated existing and new projects at LMdV, and celebrated the growing contribution of placemaking in creating better cities. Many events in the program were open to the public and included performances, panel discussions, and debates on the practices, challenges, successes, and impacts of placemaking.
Leveraging other experiments such as the Ocean Pool, the event enabled locals and visitors to share stories and collaborate and experience the natural, artistic, and cultural aspects of LMdV and the city of València leading to specific policy changes such as legalising busking on the waterfront.

Although experiments at LMdV addressed all aims at some level, we identified that most had a primary aim (Table 2). According to official documentation, key informant reflections, and standard metrics (visitor numbers and satisfaction, income), these interventions were

Table 2. Outcomes of selected examples of experiments at LMdV (2017-2019).

\begin{tabular}{|c|c|c|c|c|c|}
\hline Intervention & La Pergola & Veus de La Marina & Surem La Marina & Ocean Pool & $\begin{array}{l}\text { Placemaking } \\
\text { Week Europe }\end{array}$ \\
\hline Primary Aim & $\begin{array}{l}\text { Turn spaces into } \\
\text { places }\end{array}$ & $\begin{array}{l}\text { Connect with local } \\
\text { identity }\end{array}$ & $\begin{array}{l}\text { Broaden user } \\
\text { groups }\end{array}$ & $\begin{array}{l}\text { Expand public } \\
\text { uses }\end{array}$ & $\begin{array}{l}\text { Build generative } \\
\text { international } \\
\text { partnerships }\end{array}$ \\
\hline Perception & $\begin{array}{l}\text { Underutilised } \\
\text { iconic structures; } \\
\text { Historical and } \\
\text { cultural } \\
\text { significance for } \\
\text { local } \\
\text { communities; } \\
\text { Small urban } \\
\text { elements with } \\
\text { strong cultural } \\
\text { capital can have a } \\
\text { big } \\
\text { transformative } \\
\text { effect. }\end{array}$ & $\begin{array}{l}\text { Non-identifiable } \\
\text { public spaces } \\
\text { created problems } \\
\text { (e.g., mail } \\
\text { delivery, visitor } \\
\text { navigation); } \\
\text { Rich local } \\
\text { knowledge of } \\
\text { place exists; } \\
\text { Problem could be } \\
\text { solved and add } \\
\text { community value. }\end{array}$ & $\begin{array}{l}\text { YP seen as a } \\
\text { problem; } \\
\text { Lack of } \\
\text { knowledge about } \\
\text { YP's experiences } \\
\text { of LMdV and } \\
\text { desires for the } \\
\text { place. }\end{array}$ & $\begin{array}{l}\text { Swimming at } \\
\text { LMdV was a } \\
\text { valued activity in } \\
\text { the past; } \\
\text { Excluded users } \\
\text { (locals and YP) } \\
\text { proposed the } \\
\text { concept; } \\
\text { Recovering } \\
\text { swimming in the } \\
\text { harbour could } \\
\text { enhance inclusion } \\
\text { and diversify } \\
\text { users. }\end{array}$ & $\begin{array}{l}\text { International } \\
\text { events are elitist } \\
\text { and extractive; } \\
\text { Limited } \\
\text { understanding of } \\
\text { placemaking and } \\
\text { experimental } \\
\text { approaches } \\
\text { among } \\
\text { administration } \\
\text { and the public; } \\
\text { Many } \\
\text { professionals } \\
\text { keen to } \\
\text { participate in } \\
\text { rejuvenation. }\end{array}$ \\
\hline Collaboration & $\begin{array}{l}\text { Community } \\
\text { groups, music } \\
\text { schools, NGOs, } \\
\text { and local music } \\
\text { industry. }\end{array}$ & $\begin{array}{l}\text { Citizens and local } \\
\text { community } \\
\text { organisations. }\end{array}$ & $\begin{array}{l}\text { Local YP aged } \\
\text { 12-14 years and a } \\
\text { facilitating NGO. }\end{array}$ & $\begin{array}{l}\text { YP, swimming } \\
\text { clubs, and LMdV } \\
\text { employees. }\end{array}$ & $\begin{array}{l}\text { International } \\
\text { organisations } \\
\text { including } \\
\text { Placemaking X, } \\
\text { Placemaking } \\
\text { Europe, and } \\
\text { Project for Public } \\
\text { Spaces. }\end{array}$ \\
\hline Iteration & $\begin{array}{l}\text { LMdV became the } \\
\text { main site for free } \\
\text { public concerts in } \\
\text { the city. }\end{array}$ & $\begin{array}{l}\text { The results were } \\
\text { used in the } \\
\text { branding strategy } \\
\text { and a new } \\
\text { wayfinding } \\
\text { schema. }\end{array}$ & $\begin{array}{l}\text { Some ideas were } \\
\text { trialled and } \\
\text { others informed } \\
\text { experiments at } \\
\text { LMdV. }\end{array}$ & $\begin{array}{l}\text { There is a plan to } \\
\text { expand and } \\
\text { improve the } \\
\text { facility. }\end{array}$ & $\begin{array}{l}\text { Increased local } \\
\text { and international } \\
\text { recognition of } \\
\text { LMdV; } \\
\text { Increased role of } \\
\text { LMdV in global } \\
\text { debates and } \\
\text { leadership of } \\
\text { waterfront } \\
\text { transformations. }\end{array}$ \\
\hline
\end{tabular}


'successful' in delivering improvements to LMdV aligned with the strategic goals: productive activation of the space; civic engagement and participation; and effective governance.

However, many desired interventions have not proceeded as planned. For example, one of the tools to be embedded in PmLL activities was an emotion mapping app that used geolocation, a short survey, and user-generated content to capture how people feel in different parts of LMdV, and document desirable changes. Ultimately the scale of developing and introducing the app into LMdV was inhibited by lack of organisational buy-in and resources to promote it. Consequently, the app was subsumed by other priorities and ultimately discontinued. Other projects, such as the skatepark, had challenges with securing finances and development timelines. These delays generated considerable frustration among the community involved. Lessons learned from these examples included the importance of setting clear expectations and maintaining transparency and clear communication with institutional and community constituents from the outset. Nevertheless, discontinued initiatives provided learnings and smaller scale outcomes (like the release of the final design for the skatepark) that helped build community support for future experiments.

This focus on aims and challenges raises the question of what overall impact experimentation at LMdV has had, and what lessons this case study offers for broader conceptualisations and practices of place-based experimental planning.

\section{Unsettling 'Success' and 'Failure' through Experimentation}

The case of LMdV shows how planning by experiment reconfigured a failed urban development strategy through taking a different approach to success. Certainly, 'measures' and 'outcomes' are indicative of change in respect of the three strategic goals of LMdV: economic vitality; public engagement and perception; and effective governance. Even using conventional measures, economic changes have been achieved. Since 2015, revenue at the LMdV has increased by $78 \%$. This outcome is undoubtedly linked to the increase of visitors to the Marina: By 2018, LMdV had become the second most visited site in València (7,7 million visitors). Moreover, the diversity of visitors and the relative presence of locals compared with tourists also increased (LMdV, 2019). While the significant commercial activities of LMdV were a key strategic priority for the Consorcio, experimental processes to foster transformations that reclaimed the site for citizens were also expanded and increasingly valued. With an elastic agenda and no control over the outcomes that would be generated, experimentation brought to life and empowered community voices and narratives.

Public participation and perceptions of LMdV were also transformed through the PmLL activities. Alongside greater inclusion, experimentation at LMdV sought to change how people viewed, interacted with, and felt about the site. PmLL activities focused on turning the spaces of LMdV into places by co-designing and reimagining the site with community and other stakeholders (Lorne, 2019). Specifically, interventions aimed to connect with local culture and history, diverse users, and promote new usages at the site (Figure 4). The vignettes presented above demonstrate how this approach activated actor networks, resulting in a wider distribution of power from institutional authorities and businesses towards actors who had previously been labelled as problematic or marginalised. For example, experiments such as Surem la Marina reconfigured YP as key partners in reshaping the LMdV. The project activated a different relationship with YP who had been marginalised in previous planning processes and whose presence in LMdV had been poorly understood. The increasingly positive perception of LMdV is also visible in media coverage. In 2015, prior to the implementation of the new strategy, $82 \%$ of the news coverage of LMdV was negative. By 2018, $91 \%$ of news mentioning LMdV was positive-one indication of the success of experimentation at LMdV.

With regards to effective governance, the integration of place-based and experimental planning approaches was achieved through strategic, subtle, and iterative transformations in governance and action (Bulkeley et al., 2016). The positioning of the PmLL within the strategic plan formalised the intent for the administering agency to be a partner, rather than a sponsor of change (Cohen et al., 2016). By demonstrating how experimental approaches can co-exist with good governance, the positive transformation process has shaped the political debate around LMdV. This culminated in the negotiations of the Spain's national budget for 2021 including payment for the current debt of Consorcio València 2007 (related to the America's Cup investments) as well as providing the resources and regulations to allow the Consorcio to advance the next phase of waterfront redevelopment (Europa Press, 2020). Thus, ongoing use of experimentation as relational process-involving continuous, open, reflexive cycles of perception, collaboration, and iteration-has contributed to reconfiguring even the most significant indicator of market-led planning 'failure' at LMdV-massive financial debt-as an opportunity.

Finally, the relational process of planning by experiment through commitment to perception, collaboration, and iteration has supported ongoing negotiations between competing needs and demands. Not all parties have been pleased with specific outcomes. For example, in La Pergola experiment, some residents remain in favour of the concerts and want more to be programmed, while others claim that the concerts are too noisy. Furthermore, while most of the interventions described in this article aimed to improve the inclusiveness of LMdV, some members of the community still perceive events and commercial activities such as fine 


\section{COGITATIO}
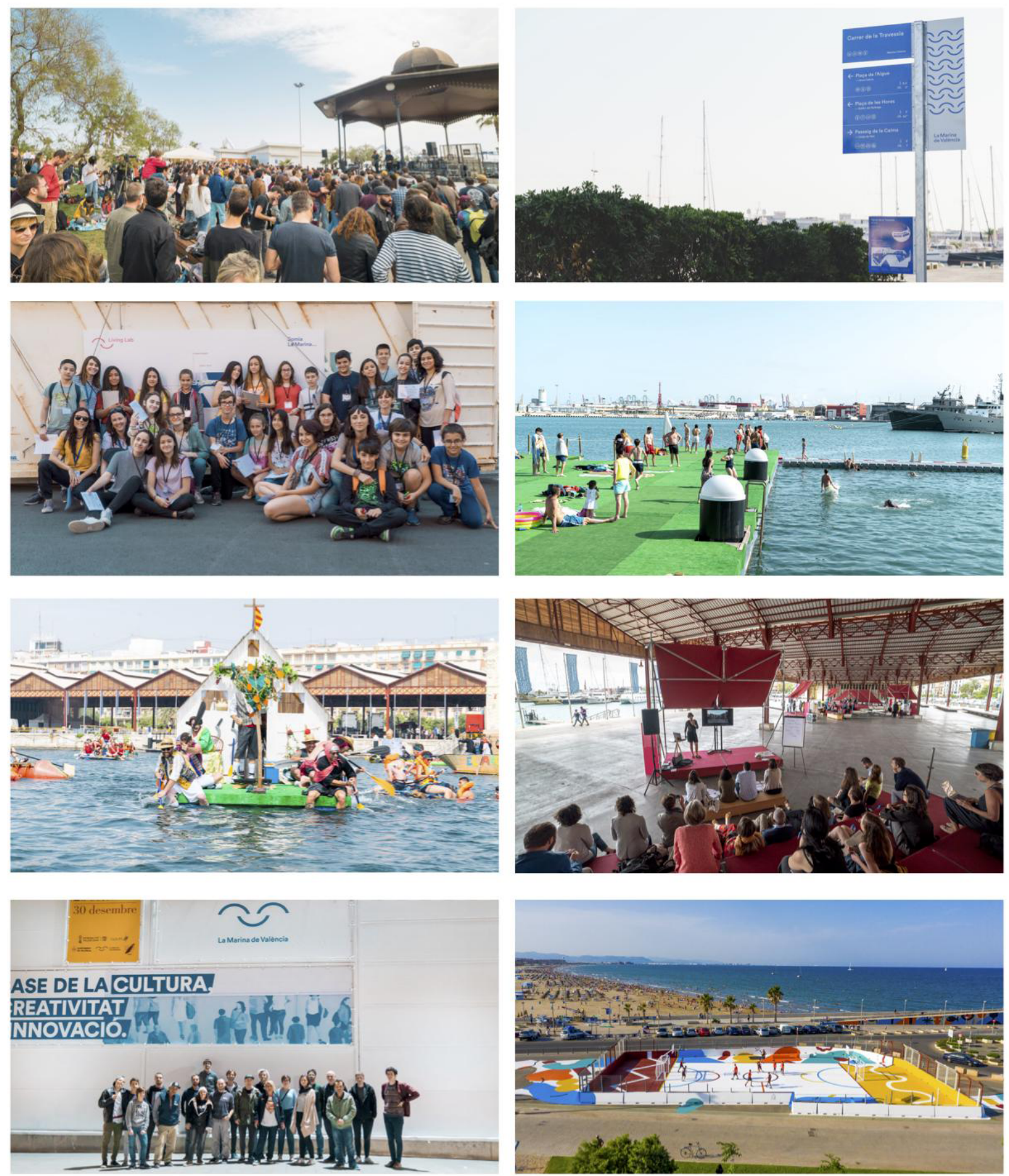

Figure 4. Experiments at LMdV. From left to right and top to bottom: Concert at La Pérgola; signals at Veus de La Marina; participants at SUREM project; ocean pool; crazy boats race; Placemaking Week; participants at a co-design workshop for the skatepark; and basketball court. Source: Courtesy of LMdV.

dining and sailing to be elitist. Nevertheless, the PmLL framework encourages working with the productive possibilities of the tensions and contradictions that surface through creative processes. Acknowledging these criticisms, testing and trialling different elements further, learning from successes and challenges and apply this knowledge, iteratively in new activities and strategies honours the complexity of the urban experiment.

\section{Conclusions: Lessons for Experimentation from a Placemaking Living Lab}

This article examines the potential of planning by experiment for the ongoing transformation of problematic city sites. By considering the literature in relationship to the case of LMdV, the article firstly contributes to an understanding of planning by experiment as relational process. 
The case of LMdV demonstrates that this relational process is not separate to but emerges from the negative impacts of other forms of centralised, top-down, or market-led planning, and is an effort to reconcile the relations between the tangible (physical) and intangible (social and cultural) features of a site.

Secondly, the article provides an empirical account of how experimentation fosters the relations of people and places, by putting people-not profits-at the centre of planning processes. From the case of LMdV, we have derived processes for operationalizing planning by experiment at strategic city sites: specifically, perception, collaboration, and iteration. We suggest these processes could be usefully applied to other sites where experimental approaches could assist in shifting the mode of planning to achieve different outcomes. The case of LMdV suggests these processes are useful for guiding administrative actors to leverage diverse knowledges through collaborative and co-creative practices, as a continuous process to generate new, meaningful place-based experiences. Through this, failure is fundamentally reconfigured as ongoing learning and 'success' can be understood as the evolving (commitment to) shared value generated between places, people, uses, and local-global networks.

By discussing the pitfalls of historic planning approaches in the context of an iconic waterfront development, and then discussing the approaches, participants, and outputs of urban experimentation processes, we have shown how an experimental planning approach can help address past failures of planning. In the context of LMdV, the turn to experiment directly reconfigured the goals, processes, and participants in planning to activate the site through prioritising actions that aimed to uncover the history and potential of the relationship of people to the space. Such an approach has gone some way to interrupting hierarchical structures and traditional power relations by opening up networks of exchange and connectivity. The case demonstrates that, when mobilised through approaches such as placemaking and ULL, experimentation can support transforms in traditional planning, becoming an integral and generative tool of urban development that brings valued form to urban futures. Or at least, in a practical way, the case of LMdV shows experimentation can foster new uses and ideas, where concrete alone does not.

\section{Acknowledgments}

We would like to acknowledge our colleagues in this work at El Consorcio València 2007 and Western Sydney University, particularly Dima Yankova, Marta Pérez Coll, Eleonora Rugiero, and Amanda Third. We also thank the reviewers whose comments were so helpful in the development of this article.

\section{Conflict of Interests}

The authors declare no conflict of interests.

\section{References}

Ansell, C., \& Bartenberger, M. (2016). Varieties of experimentalism. Ecological Economics, 130, 64-73.

Bell, D., \& Jayne, M. (2003). 'Design-led' urban regeneration: A critical perspective. Local Economy, 18(2), 121-134.

Boira, J. V. (2013). Puerto y ciudad en València: El tránsito hacia un modelo de uso ciudadano (1986-2013) [Port and city in Valencia: The transition to a citizen use model]. Biblio 3W: Revista Bibliográfica de Geografía y Ciencias Sociales, XVIII(1049, 25), 1-8.

Brenner, N. (2004). New state spaces. Oxford: Oxford University Press.

Brenner, N., Marcuse, P., \& Mayer, M. (2012). Cities for people, not for profit: An introduction. In N. Brenner, P. Marcuse, \& M. Mayer (Eds.), Cities for people, not for profit: Critical urban theory and the right to the city (pp. 1-10). London: Routledge.

Bulkeley, H., \& Castán Broto, V. (2013). Government by experiment? Global cities and the governing of climate change. Transactions: Institute of British Geographers, 38(3), 361-375.

Bulkeley, H., Coenen, L., Frantzeskaki, N., Hartmann, C., Kronsell, A., Mai, L., . . Palgan, Y. V. (2016). Urban living labs: Governing urban sustainability transitions. Current Opinion in Environmental Sustainability, 22, 13-17.

Caprotti, F., \& Cowley, R. (2017). Interrogating urban experiments. Urban Geography, 38(9), 1441-1450.

Cohen, B., Almirall, E., \& Chesbrough, H. (2016). The city as a lab: Open innovation meets the collaborative economy. California Management Review, 59(1), 5-13.

Cupers, K. (2004). Walking as do-it-yourself urbanism. London: Goldsmiths, University of London.

Deakin, M. (2011). Meeting the challenges of learning from what works in the development of sustainable communities. Sustainable Cities and Society, 1(4), 244-251.

El Mundo. (2018, September 13). Vuelve la Pérgola de La Marina, el ciclo musical que ha revolucionado el ocio diurno de València [La Pérgola de La Marina is back, the musical cycle that has revolutionized daytime leisure in Valencia]. El Mundo. Retrieved from https://www.elmundo.es/comunidad-Valènciana/ 2018/09/13/5b9a7fbde2704e05878b460b.html

Europa Press. (2020, October 28). El Gobierno condona la deuda de la Marina de València ante el Tesoro Público en los PGE 2021 [The Government forgives the debt of the Marina de València to the Public Treasury in the State Budget 2021]. Europa Press. Retrieved from https://www.europapress.es/ comunitat-Valenciana/noticia-gobierno-condonadeuda-marina-Valencia-tesoro-publico-pge-202120201028184632.html

Evans, J., Karvonen, A., \& Raven, R. (2016). The experimental city: New modes and prospects of urban 
transformation. In J. Evans, A. Karvonen, \& R. Raven (Eds.), The experimental city (pp. 1-12). Oxon and New York, NY: Routledge.

Farias, I., \& Bender, T. (2010). Urban assemblages (1st ed.). London: Routledge.

Fincher, R., Pardy, M., \& Shaw, K. (2016). Place-making or place-masking? The everyday political economy of "making place." Planning Theory \& Practice, 17(4), 516-536.

Flyvbjerg, B. (2005). Machiavellian megaprojects. Antipode, 37(1), 18-22.

Freestone, R., \& Gibson, C. R. (2006). The cultural dimension of urban planning strategies: An historical perspective. In J. Monclus \& M. Guardia (Eds.), Culture, urbanism and planning (pp. 21-41). Farnham: Ashgate.

Hall, T., \& Barrett, H. (2012). Urban geography (4th ed.). London: Routledge.

Hes, D., Mateo-Babiano, I., \& Lee, G. (2019). Fundamentals of placemaking for the built environment: An introduction. In D. Hes \& C. Hernandez-Santin (Eds.), Placemaking fundamentals for the built environment (pp. 1-14). Basingstoke: Palgrave Macmillan.

Jacobs, J. (1969). The economy of cities. New York, NY: Vintage Books.

Karvonen, A., \& van Heur, B. (2014). Urban laboratories: Experiments in reworking cities. International Journal of Urban and Regional Research, 38(2), 379-392.

Kennedy, L. (2015). The politics and changing paradigm of megaproject development in metropolitan cities. Habitat International, 45, 163-168.

Kitchin, R., Valentine, G., \& Hubbard, P. (2004). Key thinkers on space and place. London and Thousand Oaks, CA: Sage.

La Marina de València. (2017). Plan estratégico 2017-2021 [Strategic plan 2017-2021]. València: La Marina de València.

La Marina de València. (2019). La Marina de València impact report (Vol. 2, March 2019). València: La Marina de València. Retrieved from www. lamarinadevalencia.com/mreal/uploaded/memoria_ 2018_web_ingl.pdf

La Marina de València. (2020). La Marina de València impact report (Vol. 3, April 2020). València: La Marina de València.

Laidley, J. (2007). The ecosystem approach and the global imperative in Toronto's central waterfront. Cities, 24(4), 259-272.

Levinthal, D. A., \& March, G. J. (1993). The myopia of learning. Strategic Management Journal, 14(S2), 95-112.

Lorne, C. (2019). The limits to openness: Co-working, design and social innovation in the neoliberal city. Environment and Planning A: Economy and Space, 52(4), 747-765.

Lovering, J. (2009). The recession and the end of planning as we have known it. International Planning Studies, 14(1), 1-6.
Marshall, R. (2001). Waterfront in post-industrial cities. London: Spon Press.

Massey, D. (1994). Space, place and gender. Minneapolis, $\mathrm{MN}$ : University of Minnesota Press.

Mussi, E., Steinmetz, C., Evans, C., \& Corkery, L. (2020). Public participation: A sustainable legacy for Olympic Parks. In R. Roggema \& A. Roggema (Eds.), Smart and sustainable cities and buildings (pp. 335-349). Cham: Springer.

Orueta, F., \& Fainstein, S. (2008). The new mega-projects: Genesis and impacts. International Journal of Urban and Regional Research, 32(4), 759-767.

Parker, G., Street, E., \& Wargent, M. (2018). The rise of the private sector in fragmentary planning in England. Planning Theory \& Practice, 19(5), 734-750.

Parker, G., Wargent, M., Linovski, O., Schoneboom, A., Gunn, S., Slade, D., . . . Tasan-Kok, T. (2020). The future of the planning profession. Planning Theory \& Practice, 21(3), 453-480.

Pickvance, C. (1982). Physical planning and market forces in urban development. In C. Paris (Ed.), Critical readings in planning theory (pp 69-82). Oxford: Pergamon Press.

Project for Public Spaces. (2007). What is placemaking? Project for Public Spaces. Retrieved from https:// www.pps.org/article/what-is-placemaking

Prytherch, D. L., \& Boira, J. V. (2009). City profile: Valencia. Cities, 26(2), 103-115.

Raven, R., Sengers, F., Spaeth, P., Xie, L., Cheshmehzangi, A., \& de Jong, M. (2019). Urban experimentation and institutional arrangements. European Planning Studies, 27(2), 258-281.

Romero, J., Melo, C., \& Brandis, D. (2015). The neoliberal model of the city in Southern Europe. A comparative approach to Valencia and Madrid. In J. Knieling and F. Othengrafen (Eds.), Cities in crisis: Reflections on the socio-spatial impacts of the economic crisis and the strategies and approaches applied by Southern European cities (pp. 73-93). Abingdon: Routledge.

Sandercock, L., \& Dovey, K. (2002). Pleasure, politics and the "public interest": Melbourne's riverscape revitalisation. Journal of the American Planning Association, 68(2), 151-168.

Scholl, C., \& Kemp, R. (2016). City labs as vehicles for innovation in urban planning processes. Urban Planning, 1(4), 89-102.

Sendra, P., \& Sennett, R. (2020). Designing disorder: Experiments and disruptions in the city. London and New York, NY: Verso.

Siemiatycki, M. (2013). Riding the wave: Explaining cycles in urban mega-project development. Journal of Economic Policy Reform, 16(2), 160-178.

Smith, K. (2006). Measuring innovation. In J. Fagerberg, D. C. Mowery, \& R. R. Nelson (Eds.), The Oxford handbook of innovation (pp. 148-177). Oxford: Oxford University Press.

Smith, N. (1982). Gentrification and uneven development. Economic Geography, 58(2), 139-155. 
Soja, E. (1996). Thirdspace: Journeys to Los Angeles and other real-and-imagined places. Cambridge, MA: Blackwell.

Sorribes, J. (2015). València 1940-2014: Construcción y destrucción de la ciudad [Valencia 1940-2014: Construction and destruction of the city]. València: Universitat de València.
Steen, K., \& van Bueren, E. (2017). The defining characteristics of urban living labs. Technology Innovation Management Review, 7(7), 21-33.

Yiftachel, O., \& Huxley, M. (2000). Debating dominence and relevance: Notes on the 'communicative turn' in planning theory. International Journal of Urban and Regional Research, 24, 907-913.

\section{About the Authors}
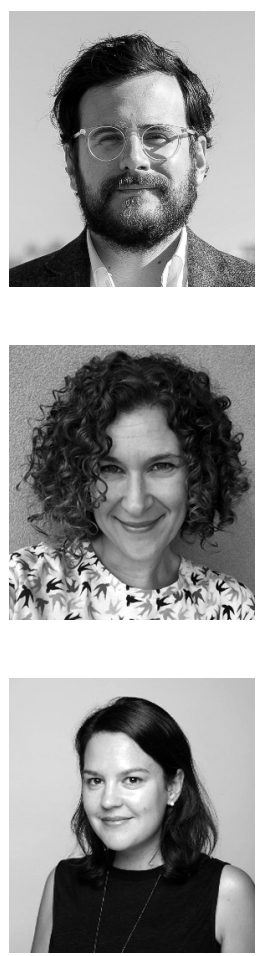

Michelle Catanzaro is a Senior Lecturer and Discipline Leader in Design, within the School of Humanities and Communication Arts, and a Research Fellow at the Young and Resilient Research Centre (Y\&RRC) at Western Sydney University. Michelle takes a transdisciplinary approach to research, combining visual communication, creative methodologies, and cultural geography.

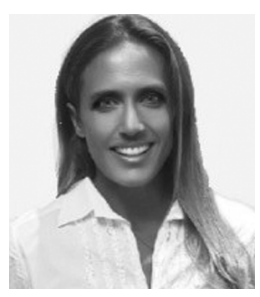

Ramon Marrades is an Urban Economist, Writer, and Activist. He is Director at Placemaking Europe and Strategy Advisor to a number of cities and large-scale development projects. Before, he has served as the Chief Strategy and Finance Officer at La Marina de València and as a Board Member for the Worldwide Network of Port Cities (AIVP). He is Co-Editor of the book "Our City? Countering Exclusion in Public Space" (2019).

Philippa Collin is Associate Professor in the Institute for Culture and Society at Western Sydney University. She researches how diverse actors mobilise to solve policy problems - and to what effectparticularly through intergenerational, participatory, and open innovation approaches. UNSW. Her research interest is on the people-place interface for the development of sustainable places that are authentic and reflective of sustainability values. 